\title{
Evaluating Pfeiffer Chromatography for Its Validation as an Indicator of Soil Quality
}

\author{
Igor Graciano, Leopoldo Sussumu Matsumoto \\ Agrarian Studies Center, State University of Northern Paraná, Rod. BR 369 Km 54 - Vila \\ Maria, Bandeirantes - Parana CEP. 86360-000, Brazil
}

Gilberto Bueno Demétrio

Soil laboratory, Agrarian Studies Center, State University of Northern Parana, Rod. BR 369

Km 54 - Vila Maria, Bandeirantes - Paraná CEP. 86360-000, Brazil

Erika Cosendey Toledo Mello Peixoto

State University of Northern Paraná, Brazil

Received: Feb. 28, 2020

Accepted: Apr. 8, 2020

Published: Apr. 13, 2020

doi:10.5296/jas.v8i3.16336

URL: https://doi.org/10.5296/jas.v8i3.16336

\begin{abstract}
Soil monitoring is fundamental to promote sustainability agroecosystems. It is necessary to consider indicators that bring together biological, physical, chemical and inter-relational attributes. Pfeiffer chromatography (PC) represents an important method for soil diagnosis, so the present study aims to analyze it in order to contribute to its validation. The soil samples of 12 production systems were evaluated in quintuplicate. The chromas were elaborated using Whatman $\mathrm{n}^{\mathrm{o}} 4$ filter paper, and the soil extract was performed by sodium hydroxide solution $1 \%$. The results were obtained using revealing solution $\left(\mathrm{AgNO}_{3} \quad 0.5 \%\right)$ ascension by capillarity, and the chrome zones: central, internal, medium and external were correlated to soil penetration, chemical, biological and enzymatic parameters, respectively. Variance analysis was applied to the results that presented normal distribution and the means were compared by Scott-Knott test. T-test for Spearman correlations and principal component analysis were used to evaluate the correlations. There was negative correlation between the central zone and the average penetration resistance within the range $0-40 \mathrm{~cm}$ in depth. The internal, medium and external zones presented positive correlation with organic matter, carbon microbial biomass, and enzymatic activities, respectively. Quality standard features such as coloration, size and proportion of zones, presence of enzymatic clouds, peaks and
\end{abstract}


radial lines were also confirmed. Thus, the standardization developed by this study contributed to validation of PC. Since PC is a low-cost and easy-to-perform method, it proves to be a useful tool allowing farmers autonomy to monitoring different agricultural systems, contributing to their production sustainable.

Keywords: circular chromatography, chroma test, fertility, soil bioindicator

\section{Introduction}

Soil analysis has contributed significantly to the development of production systems (Perumal et al., 2016). The biological component of soil represents an important factor to manage its quality, as it has a relationship with physical and chemical components, which influence crop productivity and sustainability (Mendes et al., 2015). Despite the small volume, microorganisms play a fundamental role in soil reactions, including decomposition of organic residues, nutrient cycling, formation of the stable fraction of organic matter (OM) and structure promotion (Silva et al., 2015). However, the results interpretation represents one of the major challenges in evaluating biological indicators, considering the involvement of complex factors that can interact and influence the soil environment. Another relevant aspect refers to the fact that the values considered ideal for bioindicators may vary according to the soil type and climatic conditions (Mendes et al., 2015).

The Pfeiffer chromatography (PC) represents the only chromatographic analytical method that is not just used to separate mixtures. It consists of a physical method of separating different components to characterize complex substances. At the same time, it provides a complete diagnosis of soil health by the interaction of the substances present in the sample. The integration of these substances in turn determines the formation of different patterns that are used to evaluate soil quality (Kokornaczyk et al., 2016). The chemical quality of the soil could be diagnosed by means of comparisons with a database supplied by the correlation between chromes and their respective chemical results (Perumal et al., 2016). PC also allows constant monitoring of soil response to management practices applied to different agricultural systems. It is a simple, quick and inexpensive diagnostic method, which can even be performed by the farmer himself. PC does not substitute any other chemical analysis, but its simplicity makes it possible to quickly guide soil management needs (Pfeiffer, 1984).

Although PC has already been evaluated, under experimental conditions, as an indicator used to determine mineral, organic and protein components for soil analysis (Pfeiffer, 1984; Kokornaczyk et al., 2016; Maseda, 2016), this chromatography method is unknown to farmers and specialists and it is not disseminated at universities. PC still demands specific studies on the different conditions for each system of agricultural production. The scientific contribution is not only important for its effective validation, but above all, for its greater credibility and consequent technical application. Thus, this study aims to analyze the correspondence of PC with other indicators of soil quality, in different systems of use, in order to contribute to its scientific validation. 


\section{Materials and Methods}

\subsection{Study Area}

This study was conducted at the Soil Laboratory of the State University of Northern Paraná UENP, at the Luiz Meneghel Campus (CLM) in Bandeirantes Paraná State - Brazil. The soil samples were collected at CLM under different management systems, in a commercial rural property located in the municipality of Santa Amélia and Santa Mariana at State Park Mata São Francisco. These municipalities, which are located in the third plateau, present uniform geology with an extensive volcanic lava layer that constitutes the Trapp of Paraná (Bhering, 2008). The soils of this region are classified as typical Eutrophic Red Latosol, clay texture, moderate A horizon, subperenifolia tropical forest phase and smooth undulating relief (Bhering, 2008). Due to the geological uniformity, small climatic variation and soil homogeneity extensive areas with the same pattern can be found (Brasil, 1971).

The climate of the region is Subtropical Wet Mesothermal (Cfa), with hot summers, uncommon frosts, and frequent rains in summer months. The average annual temperature corresponds to $21^{\circ} \mathrm{C}$, rainfall varies between 1200 and $1400 \mathrm{~mm}$, and the relative humidity is $75 \%$ (Köppen, 1931).

The samples were evaluated by five repetitions, from preserved areas, and those submitted to different production systems as described below (Table 1).

Table 1. Characteristics of samples sites according to their production systems

Category/Sample ID Characteristics of the Sampling Sites

Permanent preservation Forest in recovery stage, composed by pioneer species

area $(\mathrm{T} 1)$

Minimum cultivation

Crop and forest

integration (T3)

Livestock and forest integration (T4)

Agroecological transition (T5)
Rotation cultivation of Glycine max, Triticum spp., Zea mays and Avena sativa, using agricultural mechanization, railing to prepare the soil, chemical fertilization, and chemical pesticides. At collection moment there was Triticum spp.

Conventional cultivation of eucalyptus and wheat, with mechanized soil preparation, chemical fertilization, and agrochemical applications.

Eucalyptus and rotational grazing (sheep) of Cynodon plectostachyus and Panicum maximum cv. Aruan, using chemical fertilizers and swine manure annually.

Cultivated vegetables using organic fertilizer based on animal manure and green manuring. At the collect moment the area 
was fallow after green manuring.

Horta (T6)

No-tillage (T7)

Pasture (T8)

Biodynamic agriculture

Remnant of Atlantic

Forest (T10)

Permanent preservation

area in recovery $(\mathrm{T} 11)$
Conventional intensive horticulture with high degree of soil revolving, inputs, and chemical applications. There was carrot cultivated at collection moment.

Grains cultivation using biologic fertilizer (MICROGEO) and chemical control against pests. At collection moment the area was fallow with low stand of spontaneous plants and little straw from the previous maize crop.

Rotational grazing of Panicum maximum cv. Mombaça (3 days occupation dairy cattle) using chemical fertilization annually.

Olericulture using soil mechanization, bovine manure, coal, and biodynamic preparations. There were sweet potatoes at the collect moment.

Seasonal semi-deciduous forest at climax stage $\left(832.5\right.$ har $\left.^{-1}\right)$, presenting litter of $10 \mathrm{~cm}$.

Area around the source with Leucaena leucocephala managed by pruning (shallow cutting) for introduction of native species

Exposed soil area (T12) Uncovered area with periodic applications of herbicides

\subsection{Sampling and Analysis}

The composite samples were constituted by ten simple samples which were randomly collected in August 2017. The samples were collected using a Dutch auger at the depth of $0-10 \mathrm{~cm}$, weighing approximately $500 \mathrm{~g}$.

Subsequently, the samples were packed in plastic bags and transported in styrofoam boxes with ice for laboratory analysis. After that the samples were sieved in a $2 \mathrm{~mm}$ sieve, separated into plastic containers, identified and submitted to the microbial biomass carbon (MBC) analysis, respiratory activity, $\beta$-glucosidase enzyme activity (C-cycle), acid phosphatase $\mathrm{P}$ ), arylsulfatase (S-cycle), chemical analysis, granulometry analysis, and Pfeiffer chromatography. The soil samples from 12 production systems were evaluated in quintuplicate.

\subsection{Chemical Analysis}

The soil chemical analysis was performed according to the method proposed by Embrapa (2009). To evaluate the $\mathrm{pH}$, a solution of $\mathrm{CaCl}_{2} 0.01 \mathrm{~mol} \mathrm{~L}^{-1}$ was used (1 soil:2.5 solution). 
Phosphorus, potassium (available by Mehlich-1), calcium, magnesium, aluminium (exchangeable by $\left.\mathrm{KCl} 1 \mathrm{~mol} \mathrm{~L}^{-1}\right)$, potential acidity $(\mathrm{H}+\mathrm{Al}$ with calcium acetate buffer solution in $\mathrm{pH} 7,0$ ) and based on these results, the sum of bases, cation exchange capacity, base saturation, and aluminium saturation were calculated (Embrapa, 2009).

\subsection{Physical Analysis}

The determination of soil resistance to penetration was carried out using an impact penetrometer (IAA/ Planalsucar-Stolf), evaluating four points for each soil system sampled, at a depth of 0-40 cm. The determination of the granulometry composition was performed, in triplicate, by the hydrometer method. Chemical dispersant $\left(\mathrm{NaOH} 1 \mathrm{~mol} \mathrm{~L}^{-1}\right)$ was added and stirring was conducted for 15 minutes using an electric stirrer (Embrapa, 1997).

\subsection{Microbiological Analysis}

For the MBC analyses, the samples were kept for 24 hours in a refrigerator at $4{ }^{\circ} \mathrm{C}$, and then were dried in ambient air, and stored in a freezer at $-4^{\circ} \mathrm{C}$ for up to 20 days. For chemical analysis, the soil samples were air-dried and maintained for 30 days at room temperature. The MBC was determined by the fumigation (De-Polli and Guerra 1997), and the soil microbial respiration $(\mathrm{RB})$ was determined by quantifying the evolution of $\mathrm{C}-\mathrm{CO}_{2}$ (Jenkinson and Powlson, 1976).

The total organic carbon (TOC) was determined by wet oxidation with potassium dichromate $\left(\mathrm{K}_{2} \mathrm{Cr}_{2} \mathrm{O}_{4} 0,75 \mathrm{~mol} \mathrm{~L}^{-1}\right)$ and sulphuric acid $\left(\mathrm{H}_{2} \mathrm{SO}_{4} 0,5 \mathrm{~mol} \mathrm{~L}^{-1}\right)$, according to Walkley and Black (1934), modified by Tedesco et al. (1995). Metabolic quotient $\left(q \mathrm{CO}_{2}\right)$ was determined by the released C-CO $\mathrm{CO}_{2}$ ratio / MBC (Anderson and Domsch 1993), and the microbial quotient $(q \mathrm{MIC})$ was calculated by the ratio between MBC and TOC (Wardle 1994).

The evaluation of the enzymatic activity of the soil was realized according to Dick et al. (1996) with an adaptation proposed by Verchot and Borelli (2005), which does not require the use of toluene, considering that there was no difference between the samples treated or not with this inhibitor of microbial activity.

\subsection{Pfeiffer Chromatography $(P C)$}

The samples were air-dried, kept for 30 days at room temperature, sieved into $2 \mathrm{~mm}$ mesh sieves, macerated in a pistil mortar, then sieved into $0.125 \mathrm{~mm}$ mesh sieves. The soil samples of each production system were evaluated in duplicate.

The PC was elaborated on a single day, in order to provide the same ambient temperature conditions between 23 and $30{ }^{\circ} \mathrm{C}$, and relative humidity (UR) between 60 and $75 \%$, according to Pfeiffer (1984) and Restrepo and Pinheiro (2011), adapted by Balzer-Graf and Balzer (1989). This adaptation was necessary to promote better diffusion control by the establishment of $0.5 \mathrm{~mL}$ for revealing solution and $1.3 \mathrm{~mL}$ for the soil extracts. 


\subsubsection{Extraction of Soil Samples (1\% NaOH Extraction Solution)}

The samples were dried in a ventilated environment, protected from light, for 12 hours. After that, they were sieved into $2 \mathrm{~mm}$ mesh sieves, macerated in a pistil mortar, and again sieved into $0.125 \mathrm{~mm}$ mesh sieves.

For each $5 \mathrm{~g}$ of soil sample, $50 \mathrm{~mL}$ of $1 \% \mathrm{NaOH}$ (Sodium Hydroxide) was added. Subsequently, orbital shaking was performed at $220 \mathrm{rpm}$ during one minute, for three times with intervals of 0 , 15 and 60 minutes. After the last stirring, the samples remained in decantation for five hours in order to obtain the supernatant (soil extract).

\subsubsection{Filter Paper Preparation}

The center of Whatman $\mathrm{n}^{\circ} 4$ (diameter $15 \mathrm{~cm}$ ) filter papers was identified, and two marks were placed at 3.8 and $6 \mathrm{~cm}$ from the center on both Cartesian axes. The distance of $3.8 \mathrm{~cm}$ identifies the limit for the diffusion of revealing solution (AgNO3 0.5\%), and the distance of $6 \mathrm{~cm}$ identifies the limit for the diffusion of soil extract.

\subsubsection{Impregnation of Filter Paper With Revealing Solution $\left(\mathrm{AgNO}_{3} 0.5 \%\right)$}

The filter papers were impregnated with revealing solution by capillarity. For this procedure, $2 \times 2 \mathrm{~cm}$ squares were designed by using the same filter paper previously described, and then they were rolled into a cylindrical format to be used for directing the revealing solution ascension. To promote better diffusion control of the revealing solution, only $0.5 \mathrm{~mL}$ per filter paper was used, as indicated by Balzer-Graf and Balzer (1989). Subsequently, the filter papers were dried in a light-free place for 3 consecutive hours.

\subsubsection{Soil Extracts Diffusion}

After 5 hours of soil extract decantation, the same diffusing process previously described for the revealing solution was performed. By doing so, the soil extracts diffused up to the mark of $6 \mathrm{~cm}$ away from the filter paper center. For better control of the diffusion, $1.3 \mathrm{~mL}$ of revealing solution was used, according to Balzer-Graf and Balzer (1989).

\subsubsection{Revelation, Characterization and Evaluation of Chroma}

Filter papers were deposited on sulphite paper during 30 minutes for pre-drying, and then they were exposed for seven consecutive days to indirect ambient lighting conditions, on sunny days, as recommended by Pfeiffer (1984). After the revelation, in order to preserve the quality of the images, the chromas were scanned.

The chromas were evaluated considering the central zone $(\mathrm{CZ})$ which reflects soil aeration conditions, the internal zone (IZ) that corresponds to mineral development, the mean zone (MZ) that is related to the organic matter, and the external zone (EZ) that is related to the enzymatic or nutritional activity (Pfeiffer, 1984; Restrepo and Pinheiro, 2011). Thus, for the previously described samples (T1-T12), each chroma zone was evaluated in duplicate.

In addition, considering that PC is a qualitative method, the chroma was also classified by using a scale of categorization (Soiltech Solutions), with the following modifications: for CZ, 
the size and coloration criteria were considered, for IZ the radial lines and the integration with the other zones were evaluated, regarding $\mathrm{MZ}$ the size and shape of the terminations were evaluated, and for EZ the staining and format were evaluated. A general note was established for each chroma, considering the criteria described above, the proportion between zones, the transition between them, the general appearance of chroma as well as the harmony between colors, sizes, and shapes.

\subsection{Statistical Analysis}

The results that presented a normal distribution were submitted to an analysis of variance, and the means were compared by the Scott-Knott test at 5\% of significance. The correlations were analyzed by the t-test for Spearman correlations and principal component analysis. The results were processed using software R version 5.0 (R Core Team 2016).

\section{Results and Discussion}

\subsection{Chemical and Granulometry Analysis}

The soil samples, T1-T12, presented clayey textural class, but they have different levels of nutrients, according to the results presented in Table 2.

Table 2. Chemical and granulometry characteristics of each sample according to its respective systems of soil use (T1- T12)

\begin{tabular}{|c|c|c|c|c|c|c|c|c|c|c|c|}
\hline Sample & $\mathrm{P}$ & $\mathrm{OM}$ & $\mathrm{pH}$ & $\mathrm{Al}^{3+}$ & $\mathrm{H}+\mathrm{Al}$ & $\mathrm{Ca}^{2+}$ & $\mathrm{K}^{+}$ & $\mathrm{Mg}^{2+}$ & $\mathrm{BS}$ & CEC & Clay \\
\hline ID & $\mathrm{mg} \mathrm{Kg}^{-1}$ & $\mathrm{~g} \mathrm{Kg}^{-1}$ & $\mathrm{CaCl}_{2}$ & & & ....cmo & $1 \mathrm{Kg}^{-1}$ & & & & $\%$ \\
\hline $\mathrm{T} 1$ & $10.6 \mathrm{e}$ & $26.5 \mathrm{c}$ & $5.5 \mathrm{c}$ & $0.0 \mathrm{c}$ & $3.60 \mathrm{c}$ & $8.22 \mathrm{a}$ & $0.46 \mathrm{e}$ & $1.9 \mathrm{c}$ & $10.6 b$ & $14.2 \mathrm{a}$ & $73.6 \mathrm{a}$ \\
\hline $\mathrm{T} 2$ & $19.7 \mathrm{~d}$ & $24.4 \mathrm{~d}$ & $4.6 \mathrm{e}$ & $0.3 \mathrm{~b}$ & $6.66 \mathrm{a}$ & $4.44 \mathrm{~d}$ & $0.53 \mathrm{e}$ & $3.2 \mathrm{a}$ & $8.2 \mathrm{c}$ & $14.8 \mathrm{a}$ & $74.0 \mathrm{a}$ \\
\hline $\mathrm{T} 3$ & $20.8 \mathrm{~d}$ & $23.4 \mathrm{~d}$ & $5.3 \mathrm{~d}$ & $0.0 \mathrm{c}$ & $3.82 \mathrm{c}$ & $6.64 \mathrm{c}$ & $0.91 \mathrm{c}$ & $3.0 \mathrm{a}$ & $10.6 \mathrm{~b}$ & $14.4 \mathrm{a}$ & $74.0 \mathrm{a}$ \\
\hline $\mathrm{T} 4$ & $11.4 \mathrm{e}$ & $26.0 \mathrm{c}$ & $5.8 \mathrm{~b}$ & $0.0 \mathrm{c}$ & $2.74 \mathrm{~d}$ & $8.04 \mathrm{a}$ & $0.91 \mathrm{c}$ & $2.8 \mathrm{a}$ & $1.8 \mathrm{a}$ & $14.5 \mathrm{a}$ & $73.6 \mathrm{a}$ \\
\hline $\mathrm{T} 5$ & $23.0 \mathrm{c}$ & $26.8 \mathrm{c}$ & $6.3 \mathrm{a}$ & $0.0 \mathrm{c}$ & $2.15 \mathrm{e}$ & $8.30 \mathrm{a}$ & $1.02 \mathrm{~b}$ & $1.8 \mathrm{c}$ & $11.1 \mathrm{~b}$ & $13.2 \mathrm{~b}$ & $73.6 \mathrm{a}$ \\
\hline T6 & $104.7 \mathrm{a}$ & $19.6 \mathrm{e}$ & $5.7 \mathrm{~b}$ & $0.0 \mathrm{c}$ & $2.95 \mathrm{~d}$ & $8.08 \mathrm{a}$ & $0.65 \mathrm{~d}$ & $1.8 \mathrm{c}$ & $10.5 \mathrm{~b}$ & $13.5 \mathrm{~b}$ & $74.0 \mathrm{a}$ \\
\hline $\mathrm{T} 7$ & $18.9 \mathrm{~d}$ & $22.3 \mathrm{~d}$ & $4.7 \mathrm{e}$ & $0.2 \mathrm{~b}$ & $5.15 \mathrm{~b}$ & $4.32 \mathrm{~d}$ & $0.52 \mathrm{e}$ & $2.6 \mathrm{~b}$ & $7.4 \mathrm{~d}$ & $12.5 \mathrm{c}$ & $74.0 \mathrm{a}$ \\
\hline $\mathrm{T} 8$ & $4.8 \mathrm{~g}$ & $34.4 \mathrm{a}$ & $5.3 \mathrm{~d}$ & $0.0 \mathrm{c}$ & $3.60 \mathrm{c}$ & $7.44 \mathrm{~b}$ & $0.62 \mathrm{~d}$ & $2.3 \mathrm{~b}$ & $10.4 \mathrm{~b}$ & $13.7 \mathrm{~b}$ & $73.6 \mathrm{a}$ \\
\hline T9 & $33.2 \mathrm{~b}$ & $26.8 \mathrm{c}$ & $6.2 \mathrm{a}$ & $0.0 \mathrm{c}$ & $1.83 \mathrm{e}$ & $7.66 \mathrm{a}$ & $1.42 \mathrm{a}$ & $2.8 \mathrm{a}$ & $11.9 \mathrm{a}$ & $13.8 \mathrm{a}$ & $68.3 c$ \\
\hline
\end{tabular}




\begin{tabular}{ccccccccccccc} 
T10 & $1.7 \mathrm{~h}$ & $33.6 \mathrm{a}$ & $4.3 \mathrm{f}$ & $0.5 \mathrm{a}$ & $5.02 \mathrm{~b}$ & $3.02 \mathrm{e}$ & $0.13 \mathrm{~g}$ & $1.3 \mathrm{~d}$ & $4.4 \mathrm{e}$ & $9.5 \mathrm{~d}$ & $71.6 \mathrm{~b}$ \\
$\mathrm{~T} 11$ & $1.8 \mathrm{~h}$ & $30.6 \mathrm{~b}$ & $5.1 \mathrm{~d}$ & $0.0 \mathrm{c}$ & $3.76 \mathrm{c}$ & $7.30 \mathrm{~b}$ & $0.28 \mathrm{f}$ & $3.2 \mathrm{a}$ & $10.8 \mathrm{~b}$ & $14.5 \mathrm{a}$ & $73.6 \mathrm{a}$ \\
$\mathrm{T} 12$ & $7.2 \mathrm{f}$ & $15.0 \mathrm{f}$ & $4.7 \mathrm{e}$ & $0.2 \mathrm{~b}$ & $3.71 \mathrm{c}$ & $3.08 \mathrm{e}$ & $0.19 \mathrm{~g}$ & $1.6 \mathrm{c}$ & $4.9 \mathrm{e}$ & $8.6 \mathrm{e}$ & $74.0 \mathrm{a}$ \\
$\mathrm{F}$ & 900.5 & 25.6 & 58.9 & 29.9 & 41.1 & 82.2 & 159.3 & 26.9 & 152.2 & 73.0 & 17.3 \\
\hline C.V. & 9.67 & 9.45 & 3.40 & 64.9 & 12.5 & 7.9 & 10.4 & 12.2 & 4.9 & 4.0 & 0.94
\end{tabular}

$\mathrm{CV}$ : Coefficient of variation. Means followed by equal letters in the columns do not differ by Scott-Knott test (5\% probability).

MO: organic matter; BS: sum of bases; CEC: cation-exchange capacity; cmol $\mathrm{Kg}^{-1}$ : centimoles per kilogram of soil

Samples ID: permanent preservation area (T1), minimum cultivation (T2), crop and forest integration (T3), livestock and forest integration (T4), agroecological transition (T5), horta (T6), no-tillage (T7), pasture (T8), biodynamic agriculture (T9), remnant atlantic forest (T10), permanent preservation area in recovery (T11) and exposed soil area (T12).

Different soil use and management influenced organic matter concentration, where the highest values were found in T8, T10 and T11. The well-managed pasture soils tend to present high organic matter content since the dense root system of grasses with high lignin content favors this accumulation (Primavesi, 1982). The same happens with forest soils, which present intense deposition of complex vegetal residues (Júnior et al., 2017).

In mechanized agricultural systems (T2, T3 and T6), the soil revolving causes breakage of the aggregates and exposure of organic matter fractions to oxidation, accelerating their decomposition (Freitas, 2017). At T12, the low organic matter content is due to the fact that the soil is kept uncovered, without replacement of carbon sources and exposed to high temperatures, favoring the mineralization (Moreira and Siqueira 2006).

Brazilian soils, in general, have low amounts of phosphorus (Bastos et al., 2008), and the content of $3 \mathrm{mg} \mathrm{Kg}^{-1}$ in soils with more than $60 \%$ of clay, is considered critical (Malavolta, 1980). The highest concentrations of this element were found in cultivated soils (T2, T3, T5, T6, T7 and T9), which can be explained by the use of phosphate fertilizers. In forest environments (T10) the low nutrient content can be explained by the low concentration of cations of the latosols and by their high degree of weathering (Portugal et al., 2008).

The values of active acidity $(\mathrm{pH})$ also varied between the systems, presenting behavior similar to that shown by the $\mathrm{Ca}^{2+}$ content, which is generally found in low concentration in acidic soils (Malavolta, 1980). The low levels of $\mathrm{Ca}^{2+}$ and high acidity in soils growing grains (T2 and T7) are probably due to the great export by the crops, leaching, intensification of the organic matter cycle and by fertility management itself, with the use of fertilizers with acidifying effect. This process results in loss of exchangeable bases and an increase in the 
content of hydrogen and aluminium (Malavolta, 1980).

Concerning T10, the acidity may be related to the higher content of organic matter, since it presents several functional groups, especially the carboxylic and phenolic groups, which can release $\mathrm{H}^{+}$to the exchange complex (Rangel and Silva, 2007). For T12 system, the values of $\mathrm{pH}$ and $\mathrm{Ca}^{2+}$ are basically due to the intensity of the erosion and leaching processes, which results in loss of exchangeable bases and an increase in the content of hydrogen and aluminium (Malavolta, 1980).

In general, the $\mathrm{Mg}^{2}$ content, despite the different concentrations among the systems evaluated, showed a balanced relation with $\mathrm{Ca}^{2}$ e $\mathrm{K}$. The balance of cation concentration is more important than its quantity because the competition for adsorption sites can affect plant growth (Moreira et al., 1999).

3.2 Microbial Biomass Carbon (MBC), Total Organic Content (TOC) e Microbial Quotient (qMIC)

The bioindicators of soil quality presented different qualities, according to Table 3 .

Table 3. Values of microbial biomass carbon (MBC), basal respiration (BR), total organic content (TOC), microbial quotient $(q \mathrm{MIC})$, and metabolic quotient $\left(q \mathrm{CO}_{2}\right)$, of each sample according to its respective systems of soil use (T1- T12).

\begin{tabular}{|c|c|c|c|c|c|c|c|c|}
\hline Soil & $\mathrm{MBC}$ & $\mathrm{BR}$ & TOC & $q \mathrm{MIC}$ & $q \mathrm{CO}_{2}$ & $\begin{array}{l}\text { phospha- } \\
\text { tase }\end{array}$ & $\begin{array}{l}\text { Arylsulfa-t } \\
\text { ase }\end{array}$ & $\begin{array}{l}\beta \text {-glucosi- } \\
\text { dase }\end{array}$ \\
\hline & $\begin{array}{l}\mathrm{mg} \mathrm{C} \mathrm{Kg}^{-1} \\
\text { soil }\end{array}$ & $\begin{array}{l}\mathrm{mg} \\
\mathrm{C}-\mathrm{CO}_{2} \\
\mathrm{Kg}^{-1} \\
\text { soil h}^{-1}\end{array}$ & $\mathrm{~g} \mathrm{Kg}^{-1}$ & $\%$ & $\begin{array}{l}\mathrm{mg} \\
\mathrm{C}-\mathrm{CO}_{2} \\
\mathrm{~g}^{-1} \\
\text { MBS C } \\
\mathrm{h}^{-1}\end{array}$ & \multicolumn{3}{|c|}{ mg p-nitrofenol $\mathrm{Kg}^{-1}$ soil $\mathrm{h}^{-1}$} \\
\hline $\mathrm{T} 1$ & $118.33 \mathrm{~d}$ & $0.43 \mathrm{~d}$ & $15.11 \mathrm{~b}$ & $0.79 \mathrm{~d}$ & $3.64 \mathrm{c}$ & $646.18 \mathrm{~b}$ & $166.42 \mathrm{a}$ & $112.46 \mathrm{~b}$ \\
\hline $\mathrm{T} 2$ & $122.60 \mathrm{~d}$ & $0.24 \mathrm{f}$ & $14.18 \mathrm{c}$ & $0.86 \mathrm{~d}$ & $1.98 \mathrm{~d}$ & $480.97 \mathrm{c}$ & $47.37 \mathrm{~d}$ & $104.67 \mathrm{~b}$ \\
\hline $\mathrm{T} 3$ & $135.06 \mathrm{c}$ & $0.36 \mathrm{e}$ & $13.55 \mathrm{c}$ & $1.00 \mathrm{c}$ & $2.62 \mathrm{~d}$ & $672.78 \mathrm{~b}$ & $100.14 \mathrm{c}$ & $142.92 \mathrm{a}$ \\
\hline $\mathrm{T} 4$ & $138.54 \mathrm{c}$ & $0.51 \mathrm{~d}$ & $15.11 \mathrm{~b}$ & $0.92 \mathrm{~d}$ & $3.68 \mathrm{c}$ & $708.46 \mathrm{~b}$ & $146.20 \mathrm{~b}$ & $166.02 \mathrm{a}$ \\
\hline T5 & $111.87 \mathrm{~d}$ & $0.32 \mathrm{e}$ & $15.58 \mathrm{~b}$ & $0.73 \mathrm{~d}$ & $2.83 \mathrm{~d}$ & $577.60 \mathrm{~b}$ & $103.72 \mathrm{c}$ & $142.34 \mathrm{a}$ \\
\hline T6 & $62.99 \mathrm{e}$ & $0.14 \mathrm{f}$ & $11.37 \mathrm{~d}$ & $0.56 \mathrm{e}$ & $2.16 \mathrm{~d}$ & $434.09 \mathrm{c}$ & $53.31 \mathrm{~d}$ & $84.16 \mathrm{c}$ \\
\hline $\mathrm{T} 7$ & $108.20 \mathrm{~d}$ & $0.22 \mathrm{f}$ & $12.93 \mathrm{c}$ & $0.84 \mathrm{~d}$ & $2.21 \mathrm{~d}$ & $606.24 \mathrm{~b}$ & $54.12 \mathrm{~d}$ & $119.60 \mathrm{~b}$ \\
\hline
\end{tabular}




\begin{tabular}{lrrrrrrrr} 
T8 & $253.32 \mathrm{~b}$ & $0.57 \mathrm{~d}$ & $19.94 \mathrm{a}$ & $1.27 \mathrm{~b}$ & $2.33 \mathrm{~d}$ & $923.23 \mathrm{a}$ & $156.89 \mathrm{~b}$ & $124.85 \mathrm{~b}$ \\
T9 & $52.01 \mathrm{e}$ & $1.15 \mathrm{~b}$ & $15.58 \mathrm{~b}$ & $0.34 \mathrm{e}$ & $20.65 \mathrm{a}$ & $439.87 \mathrm{c}$ & $95.64 \mathrm{c}$ & $83.84 \mathrm{c}$ \\
$\mathrm{T} 10$ & $418.55 \mathrm{a}$ & $1.53 \mathrm{a}$ & $19.48 \mathrm{a}$ & $2.16 \mathrm{a}$ & $3.59 \mathrm{c}$ & $985.96 \mathrm{a}$ & $169.22 \mathrm{a}$ & $50.74 \mathrm{~d}$ \\
$\mathrm{~T} 11$ & $159.37 \mathrm{c}$ & $0.54 \mathrm{~d}$ & $18.20 \mathrm{a}$ & $0.88 \mathrm{~d}$ & $3.41 \mathrm{c}$ & $542.09 \mathrm{c}$ & $148.33 \mathrm{~b}$ & $121.35 \mathrm{~b}$ \\
$\mathrm{~T} 12$ & $110.31 \mathrm{~d}$ & $0.90 \mathrm{c}$ & $8.72 \mathrm{e}$ & $1.33 \mathrm{~b}$ & $8.32 \mathrm{~b}$ & $424.30 \mathrm{c}$ & $21.57 \mathrm{e}$ & $40.98 \mathrm{~d}$ \\
$\mathrm{~F}$ & 108.55 & 65.78 & 27.89 & 27.13 & 139.45 & 13.88 & 66.43 & 10.29 \\
\hline $\mathrm{CV}$ & 14.18 & 20 & 9.14 & 20.24 & 20.87 & 13.75 & 10.51 & 18.68 \\
\hline
\end{tabular}

$\mathrm{CV}=$ Coefficient of variation. Means followed by equal letters in the columns do not differ by test (5\% probability).

Samples ID: permanent preservation area (T1), minimum cultivation (T2), crop and forest integration (T3), livestock and forest integration (T4), agroecological transition (T5), horta (T6), no-tillage (T7), pasture (T8), biodynamic agriculture (T9), remnant atlantic forest (T10), permanent preservation area in recovery (T11) and exposed soil area (T12).

According to Alvarez (1995) there is direct relationship between MOC and TOC. Thus, the systems that presented higher source of nutrients (as T8 and T10) contributed to the maintenance of greater microbial biomass. Conversely, the T6, T7 and T12 systems, which presented the lowest values for TOC, contributed with lower MBC values.

T6 presented low TOC and MBC possibly due to the reduced input of organic material in the soil, replaced by the use of soluble fertilizers and by the intense soil disturbance which accelerates the organic matter decomposition process (Lisboa, 2012). Although T9 had presented TOC of $15.58 \mathrm{~g} \mathrm{Kg}^{-1}$, this system presented the lowest value of MBC, along with T6. This result was attributed to the fact that the collection of the soil samples was carried out after a week of highly mechanized planting in the area, with the use of subsoilers, breaking the soil structure and exposing the protected fractions of organic matter, resulting in reduction of MBC.

Corroborating with these results, Loureiro et al. (2016) compared horticultural organic systems and found lower MBC content in intensive systems. Thus, Laurel reinforces that the great movement of soil causes a breakdown of aggregates, and consequently determines the exposure of the organic material to high temperatures, spoiling the development of microbial biomass.

The T4 and T8 systems, submitted to the constant input of organic material from animal manure, presented values corresponding to TOC 15,11 and 19,94 $\mathrm{g} \mathrm{Kg}^{-1}$, and MBC 138,54 and 253,32 $\mathrm{mg} \mathrm{C} \mathrm{Kg}^{-1}$, respectively. Corroborating with these results, Carneiro et al. (2008) 
observed $\mathrm{MBC}$ in pasture area 50\% than that found in the native cerrado forest area. In addition, the intense development of the grass root system, in the upper layer of soil, favors the development of microorganisms (Souza et al., 2010).

Regarding the $q \mathrm{MIC}$, which expresses the relationship between $\mathrm{MBC}$ and $\mathrm{TOC}$, and also indicates the quality of the organic matter, the T8, T10 and T12 systems presented higher results. The large input of organic material into T10 with a litter of $10 \mathrm{~cm}$, and intense cycling of the root system provided by the grasses, added to the constant deposition of manure at T8, justify the high $q \mathrm{MIC}$. With the increment of good quality organic material, or the end of a stressful situation, there is an important increase of microbial biomass, as well as $q \mathrm{MIC}$, although the TOC remains practically equal (Powlson and Brookes, 1987).

Considering that the $\mathrm{T} 12$ system corresponded to a soil with practically no organic material replacement, the reduced TOC value and the relatively high MBC content may indicate intense mineralization and immobilization of organic matter, since high temperatures and absence of soil revolving favors microbial activity (Da Silva, 2012). The T6 and T9 systems, whose soils are intensively revolved, have shown low values for $q$ MIC. Under stress conditions, the capacity of microorganisms to use carbon is lower, determining its decrease (Wardle, 1994).

\subsection{Basal Respiration (BR) and Metabolic Quotient ( $\left.q \mathrm{CO}_{2}\right)$}

The T2, T3, T5, T6 and T7 systems, which use mechanized soil preparation, except for T7, presented lower BR values. This practice accelerates the process of decomposition of organic matter, since it increases the microbial activity soon after perturbation. If there is not enough residue to maintain the microbial population, it decays and consequently, there is a decrease in its activity (Cherubin et al., 2015). Agricultural systems that provide soil cover maintenance tend to have stable microbial activity. This fact occurs due to the gradual contribution of carbon, lower thermal amplitude and maintenance of the moisture in the superficial layer of the soil (Bradford and Peterson, 2000).

In $\mathrm{T} 7$, the low $\mathrm{BR}$ value may be related to the recent establishment of no-tillage system, which has not yet caused an increase of TOC $\left(12.93 \mathrm{~g} \mathrm{Kg}^{-1}\right)$, and has not yet been able to supply the need for plant material except for the previous crop (maize). Another factor that may have influenced this result was the reduced plant stand at the time of soil sampling. This situation provides less presence of roots, damaging the entry of carbon substrates in the system, which in turn are important for the maintenance of microbial activity (Bopaiah and Shetti 1991).

On native forest soils (T10) there was a thick layer of litter, so the high $\mathrm{CO} 2$ release may have been due to the high waste cycling, which increases the microbial biomass and consequently the biological activity (Kuzyakov, 2010). According to Brookes (1995), the soil respiration rate depends mainly on the availability of substrate, humidity, and temperature, so in a forest environment, high levels of respiration can mean high rates of decomposition.

The T9 and T12 systems presented higher values for the metabolic quotient. This fact may indicate environments in a state of stress, with greater carbon consumption for the 
maintenance of microbial biomass. T9 suffered intense soil revolving a few days before the collection of samples, and this fact may have stimulated the microbial activity. But regarding $\mathrm{T} 12$, the stimulus could have been caused by the high temperatures of the soil due to lack of coverage. The increase of $q \mathrm{CO}_{2}$ is related to microbial biomass mineralization (Melloni et al., 2008), and it also relates to the high carbon losses with respiration (Martins el al., 2010).

\subsection{Acid Phosphatase, Arylsulfatase and $\beta$-glucosidase}

The levels of phosphatase enzyme presented the highest values for T8 and T10 systems. Conservation management with a high turnover of organic material, and low soil revolving promote a favorable environment for microorganisms and consequently provide greater enzymatic activity. The maintenance of acid phosphatase in tropical, highly weathered soil is of fundamental importance because a great proportion of the phosphorus is in the organic form, and thus, the catalytic hydrolysis may play an important role in the availability of this element (Kedi et al., 2013).

The T2, T6 and T9 systems presented low values for acid phosphatase, which reflects the impact of the soil revolving on the activity of microorganisms producing enzyme phosphatases (Nannipieri et al., 2011). Moreover, the expression of the catalytic activity of these enzymes can be influenced by the values of phosphorus in soil, $\mathrm{pH}$, temperature and organic matter (Tabatabai, 1994). This aspect may explain the low values for all the soil samples that received phosphorus based fertilization such as T2, T6 and T9, and with low TOC content such as T12.

Likewise, for arylsulfatase enzyme, the treatments with high nutrient cycling and without soil revolving like T1, T4, T8, T10 and T11, presented high values. According to Nogueira and Melo (2003) the maintenance of soil organic matter is essential for arylsulfatase activity, since the organic matter is the main reservoir source of sulfate esters, which are substrates of this enzyme. Thus, the enzymatic activity is related to the organic concentrations of carbon, which reflect the availability of substrates on which the enzymes can act (Silva et al., 2015).

The systems with low TOC (T6, T7 and T12) and which underwent soil revolving (T2, T6 and T9) presented lower values for arylsulfatase enzyme. Managements that disfavor the accumulation of organic matter and cause soil disturbance can affect populations of fungi and consequently, the activity of arylsulfatase (Lisboa, 2012). Matias et al. (2009) reported that soil revolving during agricultural activities may decrease biomass by direct damage to microbial cells.

Concerning the enzyme $\beta$-glucosidase, the T3, T4 and T5 systems demonstrated the highest values. This result was probably due to the fact that $\mathrm{T} 3$ and $\mathrm{T} 4$ corresponded to integration systems with eucalyptus (cellulose-rich species), and T5 system, which was fertilized with green manure cocktail. The enzyme $\beta$-glucosidase acts on the decomposition of soil organic matter. It is present in the final stage of cellulose biodegradation (the main component of plants polysaccharides), and it is also involved with the release of labile energy for microorganisms (Tabatabai, 1994; Martínez et al. 2007; Stott et al., 2010).

In contrast, the T6, T9, T10 and T12 systems had the lowest values for $\beta$-glucosidase. It is 
important to note that intensely mechanized soils (T6 and T9) and with low organic matter (T12) tend to present less activity of this enzyme, since $\beta$-glucosidase reflects the condition of the organic matter and the soil decomposition processes (Ferreira, 2017). However, its lower activity in T10 may be due to the greater complexity of the vegetal residues that return to the soil in this system. The carbon was not readily mineralizable, and this enzyme acts on less complex substrates (Matsuoka et al., 2003).

\subsection{Pfeiffer Chromatography}

To obtain a better set of data correlated between soil quality indicators, the PC results were categorized in scale of notes, according to Soiltech Solutions (2018) (Table 4 and Figure 1).

Table 4. Scores by scale of notes (Soiltech Solution) of the general qualitative characteristics of the zones: central (CZ), internal (IZ), middle (MZ) and external (EZ) of each sample according to its respective systems of soil use (T1- T12).

\begin{tabular}{|c|c|c|c|c|c|}
\hline Soil & $\mathrm{CZ}$ & $\mathrm{IZ}$ & $\mathrm{MZ}$ & EZ & Final score \\
\hline $\mathrm{T} 1$ & 8 & 8 & 9 & 9 & 8.5 \\
\hline $\mathrm{T} 2$ & 8 & 9 & 8 & 8 & 8 \\
\hline $\mathrm{T} 3$ & 7 & 8 & 8 & 8 & 8 \\
\hline $\mathrm{T} 4$ & 7 & 8 & 9 & 9 & 8.5 \\
\hline $\mathrm{T} 5$ & 7 & 8 & 8 & 8 & 8 \\
\hline T6 & 8 & 7 & 6 & 7 & 7 \\
\hline $\mathrm{T} 7$ & 7 & 8 & 9 & 8 & 8 \\
\hline $\mathrm{T} 8$ & 7 & 9 & 9 & 9 & 9 \\
\hline $\mathrm{T} 9$ & 8 & 6 & 4 & 5 & 5.5 \\
\hline $\mathrm{T} 10$ & 10 & 10 & 10 & 10 & 10 \\
\hline $\mathrm{T} 11$ & 8 & 8 & 9 & 9 & 8.5 \\
\hline $\mathrm{T} 12$ & 7 & 5 & 4 & 3 & 4.5 \\
\hline
\end{tabular}

Samples ID: permanent preservation area (T1), minimum cultivation (T2), crop and forest integration (T3), livestock and forest integration (T4), agroecological transition (T5), horta (T6), no-tillage (T7), pasture (T8), biodynamic agriculture (T9), remnant atlantic forest (T10), 


\section{MInstitute ${ }_{\text {Mnink }}^{\text {Macrothin }}$}

permanent preservation area in recovery (T11) and exposed soil area (T12).

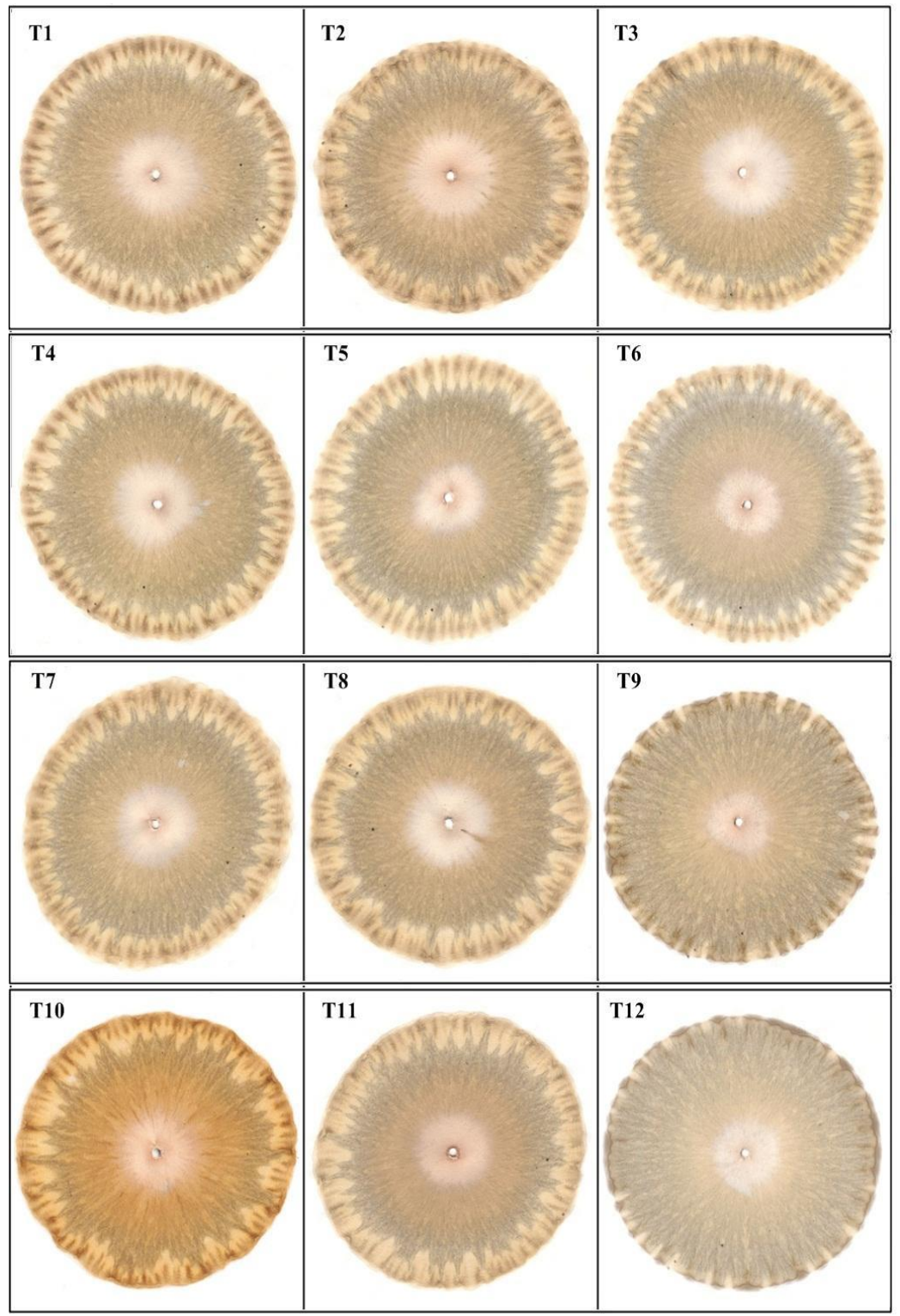

Figure 1. Pfeiffer Chromatography of the soils samples

Samples ID: permanent preservation area (T1), minimum cultivation (T2), crop and forest integration (T3), livestock and forest integration (T4), agroecological transition (T5), horta (T6), no-tillage (T7), pasture (T8), biodynamic agriculture (T9), remnant atlantic forest (T10), permanent preservation area in recovery (T11) and exposed soil area (T12).

The systems that presented lower scoring of chromas were T12 followed by T9 and T6. Negative aspects of the chromas could be observed, as follows: disproportionate zones, poorly integrated zones, darker coloration and disharmonious appearance. In T9 and T12, the MZ terminations do not show peaks, and the EZ is almost non-existent, without "enzymatic clouds". These aspects characterize soils of low biological and enzymatic activity (Pfeiffer, 1984; Restrepo and Pinheiro, 2011). 
In contrast to the systems that were described above, the chromas of T1, T2, T3, T4, T5, T7, and T11 systems presented similar characteristics, brown color, integrated zones of proportional sizes and well-marked radial structure. However, T1, T4, T8 and T11 differ from the others due to unequally distributed MZ peaks, with a mild brown color and marked formation of "enzymatic clouds" in the EZ. These factors characterize soils with adequate biological and enzymatic activity (Pfeiffer, 1984; Restrepo and Pinheiro, 2011).

Regarding T10 system, considering Pfeiffer (1984), it was possible to identify high quality soil patterns such as a harmonious relationship between the colors and sizes of the zones, integration between zones, sharpness and shape of the radiations, terminations in the form of jagged peaks of the MZ, presence of the "enzymatic clouds" in the EZ, and the shade of light brown color in every chroma, demonstrating a positive aspect of healthy soil.

According to Restrepo and Pinheiro (2011), the CZ is related to soil structure, thus this study correlated $\mathrm{CZ}$ to penetration resistance test (Table 5).

Table 5. Correlation between the central zone (CZ) and the soil resistance to penetration (RsP) $(\mathrm{cm})$

\begin{tabular}{|c|c|c|c|c|c|c|c|c|c|c|c|}
\hline & & DA & & & & $\mathrm{R}$ & $\mathrm{sP}$ & & & & DA \\
\hline & $\mathrm{CZ}$ & $0-10$ & $0-5$ & $5-10$ & $10-15$ & $15-20$ & $20-25$ & $25-30$ & $30-35$ & $35-40$ & $0-40$ \\
\hline $\mathrm{CZ}$ & 1.00 & & & & & & & & & & \\
\hline $0-10$ & -0.45 & 1.00 & & & & & & & & & \\
\hline $0-5$ & -0.49 & $0.88^{* *}$ & 1.00 & & & & & & & & \\
\hline $5-10$ & -0.47 & $0.99^{* *}$ & $0.82^{* *}$ & 1.00 & & & & & & & \\
\hline $10-15$ & -0.47 & $0.94^{* *}$ & $0.74^{* *}$ & $0.97^{* *}$ & 1.00 & & & & & & \\
\hline $15-20$ & -0.47 & $0.86^{* *}$ & $0.60^{*}$ & $0.91^{* *}$ & $0.97^{* *}$ & 1.00 & & & & & \\
\hline $20-25$ & $-0.62^{*}$ & $0.87^{* *}$ & $0.68^{*}$ & $0.91^{* *}$ & $0.94^{* *}$ & $0.95^{* *}$ & 1.00 & & & & \\
\hline $25-30$ & $-0.66^{*}$ & $0.84^{* *}$ & $0.65^{*}$ & $0.89^{* *}$ & $0.92^{* *}$ & $0.93^{* *}$ & $0.99^{* *}$ & 1.00 & & & \\
\hline $30-35$ & $-0.62^{*}$ & $0.89^{* *}$ & $0.70^{*}$ & $0.92^{* *}$ & $0.94^{* *}$ & $0.93^{* *}$ & $0.94^{* *}$ & $0.95^{* *}$ & 1.00 & & \\
\hline $35-40$ & $0.64^{*}$ & $0.88^{* *}$ & $0.70^{*}$ & $0.91^{* *}$ & $0.93^{* *}$ & $0.92^{* *}$ & $0.94^{* *}$ & $0.94^{* *}$ & $0.99^{* *}$ & 1.00 & \\
\hline $0-40$ & $0.62^{*}$ & $0.95^{\text {** }}$ & $0.81^{* *}$ & $0.97^{* *}$ & $0.96^{\text {** }}$ & $0.92^{* *}$ & $0.95^{\text {** }}$ & $0.94^{* *}$ & $0.98^{* *}$ & $0.97^{* *}$ & 1.00 \\
\hline
\end{tabular}


DA = Depth average 0-10 cm; 0-40 cm;

Spearman correlation coefficient, significance: ${ }^{*} *{ }^{\prime}=0.01{ }^{\prime}{ }^{\prime}{ }^{\prime}=0.05 ; \mathrm{n}=12$

$\mathrm{CZ}$ is also known as the zone of soil oxygenation, because it reflects the aeration conditions, besides signaling the nitrogen content. Restrepo and Pinheiro (2011) observed that compacted soils, with lower oxygen presence and tendency to anaerobic metabolism, have a dark CZ. On the other hand, well aerated soils with a tendency to aerobic metabolism show yellow and cream coloration. In soils with a high presence of soluble nitrogen, the $\mathrm{CZ}$ is present with white coloration.

According to the present study, the $\mathrm{CZ}$ showed a negative correlation with resistance to soil penetration, from the $20 \mathrm{~cm}$ depth. Regarding the average for the 0 to $40 \mathrm{~cm}$ depth range, there was also a significance level of 5\%. However, all depths expressed an inverse relationship to penetration resistance, confirming that the higher the resistance is, the lower the observed CZ quality will be.

Bezerra (2018) found a positive correlation when comparing CZ with soil macroporosity in different agroforestry systems. Soils that presented adequate values for this physical parameter received good evaluation, and those which presented inadequate values, received a negative evaluation for CZ. The macroporosity indicates the aeration capacity, as it is a measure of the diffusion rate of oxygen in the soil (Lima et al., 2017).

Concerning the IZ of the chroma, which indicates the mineral behavior of the soil (Pfeiffer, 1984), and the variables present in the chemical analysis, a positive correlation was observed with TOC (Table 6).

Table 6. Correlation between the internal zone (IZ) and the different variables of the soil chemical analysis

\begin{tabular}{|c|c|c|c|c|c|c|c|c|c|c|c|}
\hline IZ & $\mathrm{pH}$ & TOC & $\mathrm{P}$ & $\mathrm{K}$ & $\mathrm{Ca}$ & $\mathrm{Mg}$ & $\mathrm{Al}$ & $\mathrm{H}+\mathrm{Al}$ & BS & CEC & V \\
\hline \multicolumn{12}{|l|}{1} \\
\hline-0.5 & 1 & & & & & & & & & & \\
\hline $0.58^{*}$ & 0.04 & 1 & & & & & & & & & \\
\hline-0.5 & $0.64^{*}$ & -0.46 & 1 & & & & & & & & \\
\hline-0.3 & $0.80^{* *}$ & 0.01 & $0.80^{* *}$ & 1 & & & & & & & \\
\hline-0.2 & $0.86^{* *}$ & 0.13 & 0.49 & $0.61^{*}$ & 1 & & & & & & \\
\hline 0.15 & 0.01 & 0.06 & 0.14 & 0.31 & 0.02 & 1 & & & & & \\
\hline
\end{tabular}




$\begin{array}{ccccccccccccccc}0.33 & -0.83^{* *} & -0.18 & -0.36 & -0.63^{*} & -0.82^{* *} & -0.23 & 1 & & & & \\ 0.51 & -0.92^{* *} & -0.18 & -0.41 & -0.62^{*} & -0.78^{* *} & 0.22 & 0.71^{* *} & 1 & & & \\ -0.3 & 0.86^{* *} & 0.25 & 0.43 & 0.71^{* *} & 0.77^{* *} & 0.41 & -0.82^{* *} & -0.75^{* *} & 1 & & \\ 0.28 & 0.13 & 0.16 & 0.07 & 0.28 & 0.29 & 0.85^{* *} & -0.37 & 0.05 & 0.48 & 1 & \\ -0.5 & 0.97^{* *} & 0.16 & 0.55 & 0.76^{* *} & 0.88^{* *} & 0.05 & -0.84^{* *} & -0.93^{* *} & 0.88^{* *} & 0.16 & 1\end{array}$

Data: $\mathrm{IZ}=$ inernal zone; $\mathrm{TOC}=$ total organic carbon; $\mathrm{P}=$ Phosphor; $\mathrm{K}=$ potassium; $\mathrm{Ca}=$ Calcium; $\mathrm{Mg}=$ Magnesium; $\mathrm{Al}=$ Aluminum; $\mathrm{H}+\mathrm{Al}=$ Potential acidity; $\mathrm{BS}=$ Sum of bases; $\mathrm{CEC}=$ Cation exchange capacity; $\mathrm{V}=$ Saturation bases.

Spearman correlation coefficient, significance: ' $* *^{\prime}=0.01$ ' $^{*}=0.05 ; \mathrm{n}=12$

In agreement with this result, Kokornaczyk et al., (2016) correlated Pfeiffer chromatography with soil chemical variables in different management systems. These researchers found a positive correlation between the levels of organic matter and the radial formations. They still observed that these formations were associated with the positive characteristics of the soils such as high content of organic matter, nitrogen and phosphor totals.

Radial lines, which extend from the middle of the chroma and reach the EZ, correlate with the formative forces of the soil (Maseda, 2016). These forces indicate the soil's ability to provide conditions necessary for the biological development and dynamic equilibrium of the chemical and physical fractions of the system.

Restrepo and Pinheiro (2011) consider that "life is the integration of electromagnetic energies", and the "living minerals" (metabolized by microorganisms) present different electric charge and magnetism, thus they express these differences by the radiations, forms, and colors of IZ. Kokornaczyk et al., (2016) observed that radial formations and intense colors indicate good quality soil, while concentric patterns and blurred colors indicate low fertility.

The IZ also reflects the structure and capacity of soil moisture retention (Kokornaczyk et al., 2016), which refers to the decomposition of organic matter and the production of polyuronic acids, responsible for aggregation and formation of clumps (Primavesi, 1982). Thus, soils with higher organic matter and microbial activity, tend to present adequate structure, reflecting IZ with positive patterns.

For the present study, when evaluating the relationship between chroma $\mathrm{MZ}$ and biological variables $\mathrm{MBC}, \mathrm{BR}, q \mathrm{CO}_{2}, q \mathrm{MIC}$ and TOC, it was possible to observe a significant positive correlation with MBC (Table 7). 


\section{Macrothink}

Journal of Agricultural Studies

ISSN 2166-0379

2020, Vol. 8, No. 3

Table 7. Correlation between the middle zone (MZ) and the microbial biomass carbon (MBC), basal respiration $(\mathrm{BR})$, metabolic quotient $\left(q \mathrm{CO}_{2}\right)$, microbial quotient $(q \mathrm{MIC})$ and total organic content (TOC)

\begin{tabular}{ccccccc}
\hline & $\mathrm{MZ}$ & $\mathrm{MBC}$ & $\mathrm{BR}$ & $q \mathrm{CO}_{2}$ & $q \mathrm{MIC}$ & $\mathrm{TOC}$ \\
\hline $\mathrm{MZ}$ & 1.00 & & & & \\
$\mathrm{MBC}$ & $0.74^{* *}$ & 1.00 & & & \\
$\mathrm{BR}$ & 0.14 & 0.38 & 1.00 & & \\
$q \mathrm{CO}_{2}$ & -0.10 & -0.05 & $0.75^{* *}$ & 1.00 & \\
$q \mathrm{MIC}$ & 0.42 & $0.74^{* *}$ & 0.50 & 0.10 & 1.00 & \\
$\mathrm{TOC}$ & 0.55 & $0.63^{*}$ & 0.55 & 0.17 & 0.16 & 1.00 \\
\hline
\end{tabular}

Spearman correlation coefficient, significance: '**' $=0.01$; $^{*}{ }^{\prime}=0.05 ; \mathrm{n}=12$

The MZ or biological zone expresses the active processes of organic matter decomposition (Restrepo and Pinheiro, 2011). When MZ presents clear and integrated colors with IZ and EZ, it is a sign of good microbiological activity (Figure 1). This zone should present peaks of different sizes and brown color, the light colors indicate more stable processes (Restrepo and Pinheiro, 2011).

The EZ expresses complex high molecular weight substances such as proteins, enzymes, and vitamins (Pfeiffer, 1984). The EZ showed a strong positive correlation with the enzymes acid phosphatase and arylsulfatase (Table 8).

Table 8. Correlation of acid phosphatase, arylsulfatase, and $\beta$-glucosidase with external zone (EZ)

\begin{tabular}{lcccc}
\hline & EZ & Acid Phosphatase & Arylsulfatase & $\beta$-glucosidase \\
\hline EZ & 1.00 & & \\
Acid Phosphatase & $0.87^{* *}$ & 1.00 & 1.00 & \\
Arylsulfatase & $0.83^{* *}$ & $0.80^{* *}$ & 0.30 & 1.00 \\
$\beta$-glucosidase & 0.42 & 0.49 & 0.00 \\
\hline
\end{tabular}

Spearman correlation coefficient, significance: $* *=0.01 ; \mathrm{n}=12$ 


\section{Macrothink}

Journal of Agricultural Studies

ISSN 2166-0379 2020, Vol. 8, No. 3

The characteristics of EZ are remarkable and easy to observe. The presence of "enzymatic clouds", brown spots that appear between and at the end of the MZ peaks, are indications of enzymatic activity and humus formation (Pfeiffer, 1984; Restrepo and Pinheiro, 2011).

Primavesi (1982) stated that for evaluate an active and good soil, only the quantity of microorganisms is not enough. Primavesi pointed out that the microbial activity is expressed by the presence of these catalytic extracellular enzymes, representing an important parameter to be evaluated.

The eigenvector graphs of main components were constructed from the relationship between the chroma zones and the respective correlated indicators: CZ and resistance to penetration, IZ and soil chemical parameters, MZ and biological indicators, and EZ and enzymatic activity. These graphs group the treatments according to the eigenvectors, allowing the establishment of relations between the quantitative variables of the indicators and qualitative of the chroma (Figure 2). 

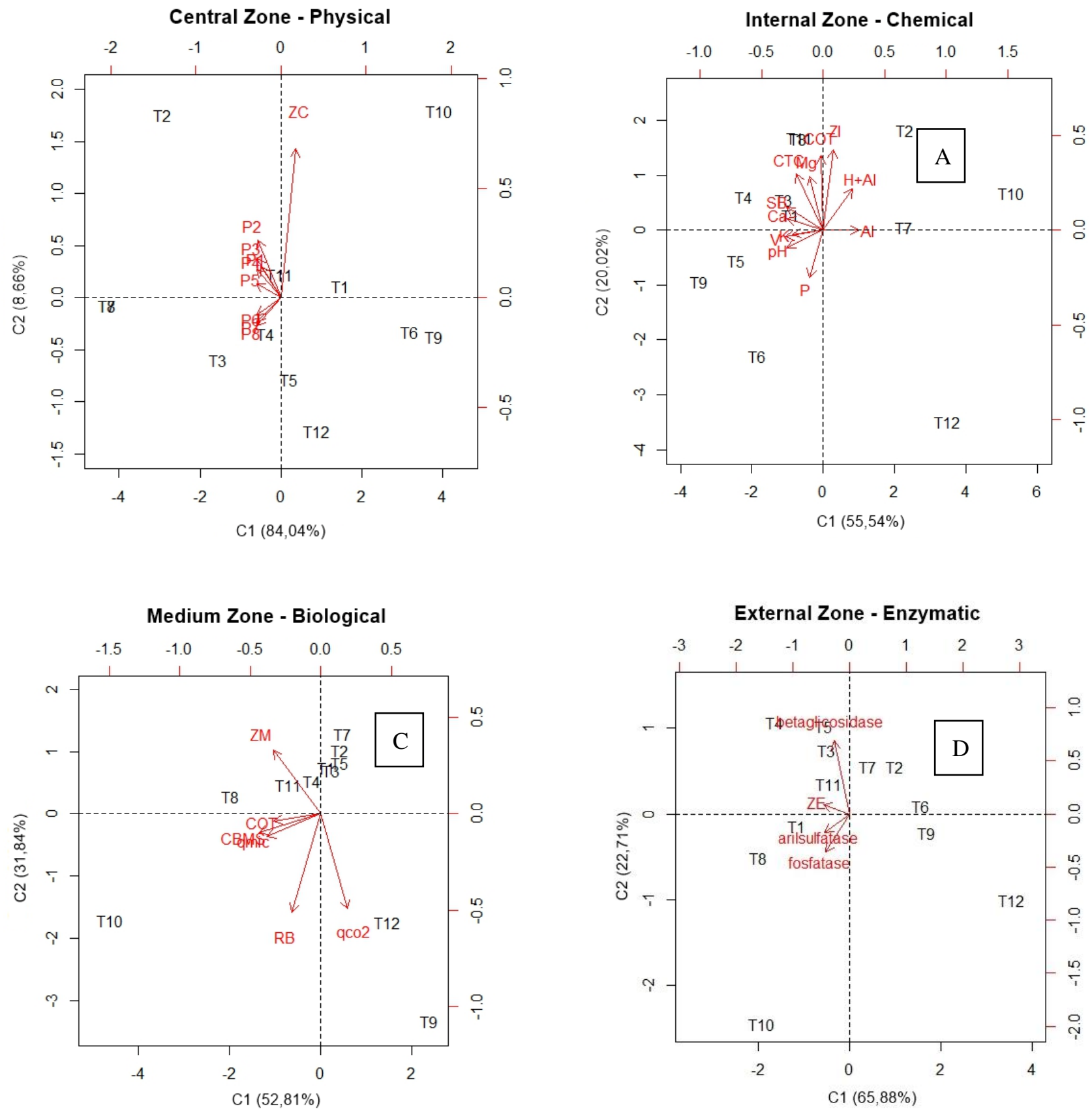

Figure 2. Eigenvector of main components ( $\mathrm{C} 1$ e $\mathrm{C} 2)$ grouped by type of variable evaluated in the respective zones, for the samples: permanent preservation (T1), minimum cultivation (T2), crop and forest integration (T3), livestock and forest integration (T4), agroecological transition (T5), horta (T6), no-tillage (T7), pasture (T8), biodynamic agriculture (T9), remnant atlantic forest (T10), permanent preservation area in recovery (T11) and exposed soil area (T12)

Data: Figure 2A = Central Zone - Physical; Figure 2B = Internal Zone - Chemical; Figure 2C $=$ Medium Zone - Biological; Figure 2D $=$ External Zone - Enzimatic .

Soil penetration: $\mathrm{P} 1=0-5 \mathrm{~cm} ; \mathrm{P} 2=5-10 \mathrm{~cm} ; \mathrm{P} 3=10-15 \mathrm{~cm} ; \mathrm{P} 4=15-20 \mathrm{~cm} ; \mathrm{P} 5=20-25 \mathrm{~cm}$; 
$\mathrm{P} 6=25-30 \mathrm{~cm} ; \mathrm{P} 7=30-35 \mathrm{~cm} ; \mathrm{P} 8=35-40 \mathrm{~cm}$; total organic content $(\mathrm{TOC})$; base sum $(\mathrm{BS})$; cation exchange capacity (CTC); base saturation (V); microbial biomass carbon (MBC); basal respiration (BR); microbial quotient ( $q \mathrm{MIC})$; metabolic

In relation to the soil physical analysis, (Figure 2A), in C1 (which expressed $84.04 \%$ of the variations), the $\mathrm{CZ}$ grouped $\mathrm{T} 1, \mathrm{~T} 5, \mathrm{~T} 6$, and $\mathrm{T} 9$ to $\mathrm{T} 12$, wich corresponded to the soils with lower resistance to penetration. The $\mathrm{CZ}$ and other zones presented common characteristics such as proportionality of each zone size, and beige coloration (Figure 1), corroborating to the patterns of structured soil described by Restrepo and Pinheiro (2011). These soils were occupied with forest (T1, T10 and T11), vegetable garden (T5, T6 and T11) and in prolonged fallow (T12), which explains the lower degree of compaction of them. On the other hand, the systemsT2, T3, T4, T7 and T8 were grouped because they present a higher value of resistance to soil penetration. The cultivation of grains or grazing results in the compaction of the soil, due to the intensive use of heavy machinery and trampling of animals. Thus, these systems presented a larger size of $\mathrm{CZ}$ with a smaller proportion in relation to the other zones, characteristics that indicate inadequate soil aeration (Pfeiffer, 1984; Restrepo and Pinheiro, 2011).

Regarding the chemical analyses, component 1 expressed $55.54 \%$ of the variations. The variables $\mathrm{H}+\mathrm{Al}$ and $\mathrm{Al}$ grouped the systems T2, T7, T10 and T12, which corresponded to the more acidic soils, and the variables $\mathrm{V}, \mathrm{SB}, \mathrm{Ca}^{2+}, \mathrm{pH}$ e $\mathrm{K}^{+}$grouped the other treatments, which correspond to the less acidic soils. For this grouping, it was not possible to observe any correlation between the common characteristics between the IZ and the acidity of the soils.

However, component 2 figure $2 \mathrm{~B}$, which expressed $20.02 \%$ of the variations, the variables IZ and TOC grouped the systemsT1, T2, T3, T4, T7, T8, T10 and T11, that correspond to the systems whose managements used low soil revolving. These chromas were distinguished from the others due to presented integrated IZ to the adjacent zones and by the coloration of brown tonality (Figure 1). In relation to the $\mathrm{P}$ content, the component 2 grouped the systemsT5, T6 and T9 that presented a high concentration of this nutrient in the soil. Note that the IZ of these chromes have a common characteristic that differs from the others, dark brown color with greenish tones between the radiations (Figure 1). However, the T12 system exhibited low phosphorus content and also presented these color patterns in IZ. This result may be related to soil chemical imbalance.

Regarding the biological analysis (Figure 2C) for component 1, which expressed $52.81 \%$ of the variations, the variables MBC, $q \mathrm{MIC}$, TOC and MZ grouped treatments T4, T8, T10 and T11, which correspond to soils of better biological quality. These soils presented as common characteristics the proportional and integrated MZ to the adjacent zones, as well as a smaller number of peaks, but with different sizes and widths, which confirms the standards of good biological quality, as indicated by Pfeiffer (1984) and Restrepo and Pinheiro (2011).

For component 2 (Figure 2C), which explained $31.84 \%$ of the variations, the variable $q \mathrm{CO}_{2}$ grouped the treatments T9 and T12, characterized as stressed environments according to the theory of Odum (1985). This theory asserts that the increase in respiration rates of the microbial population may be related to the necessity of repairing damages caused by disturbances in the soil, which requires deviation of the energy destined to the growth and 
reproduction for cellular maintenance. The chromas of these soils presented characteristics in common at the MZ: disharmonious aspect, a dark brown coloration, and a lot of uniform endings in cylindrical format (Figure 1). These characteristics confirm the negative patterns for MZ (Pfeiffer, 1984; Restrepo and Pinheiro, 2011).

As for the enzymatic analysis (Figure 2D), for the component 1, which explained $65.88 \%$ of the variations, the acid phosphatase, arylsulfatase and EZ variables grouped T1, T3, T4, T5, T8, T10 and T11 systems. These chromas presented features in common in EZ: yellow color of darker shade format (Figure 1), presence of "enzymatic clouds" and size proportional to that of the other zones, confirming the patterns of good enzymatic activity (Pfeiffer,1984; Restrepo and Pinheiro, 2011).

As for component 2, which expressed $22.71 \%$ of the variations, the $\beta$-glucosidase variable grouped the systems T2, T3, T4, T5, T6, T7 and T11. However, when the EZ of the respective chromas was evaluated, it was not possible to find differences that could distinguish them from the other systems.

In summary, it is important to emphasize the standardization and validation of this method, since it is a low cost, easy-to-perform test which allows farmers to assess land management and thus better maintain soil quality, which, consequently, leads to a more sustainable production system.

\section{Conclusion}

The central zone of the chromas showed a negative correlation with the soil penetration resistance below 20 and $40 \mathrm{~cm}$ depth. That is, the more compacted the soil, the lower the quality of the central zone, confirming the quality standards as proportional size and beige color.

The internal zone presented a positive correlation with total organic content, and sensitivity to indicate structure problems related to the intensity of soil revolving. The quality standards analyzed in the internal zone of the chromas, such as well-marked radiations, brown coloration and integration with the other zones, were confirmed in this study.

The middle zone of the chroma showed a strong positive correlation with the soil microbial biomass carbon, evidencing the relation of this zone with the soil biology. The patterns that indicate quality for this zone, such as irregular peaks, brown coloration and proportion to the other zones, were also confirmed by this study.

Regarding the external zone, there was an important positive correlation with the acid phosphatase and arylsulfatase enzymes, evidencing its relation with the enzymatic activity of the soil. "Enzymatic clouds" and yellow shades were also confirmed as indicators of quality for this area.

Finally, it was possible to conclude that Pfeiffer Chromatography has been shown to be a sensitive soil quality diagnostic method, since from the analysis and interpretation of the patterns formed in the different zones, it was possible to evaluate the physical, chemical and biological conditions of the different agricultural systems evaluated. 


\section{Acknowledgement}

To CAPES for the resources to this research and scholarships.

\section{References}

Alvarez, R. (1995). Soil organic carbon, microbial biomass and $\mathrm{CO}_{2}-\mathrm{C}$ production from tree tillage systems. Soil Tillage Research, 31, 17-28. https://doi.org/10.1016/0167-1987(94)00432-E

Anderson, T. H., \& Domsch, K. H. (1993). The metabolic quotient for $\mathrm{CO}_{2}\left(\mathrm{qCO}_{2}\right)$ as a specific activity parameter to assess the effects of environment conditions, such as $\mathrm{pH}$, on the microbial biomass of forest soils. Soil Biology Biochemistry, 25(3), 393-395. https://doi.org/10.1016/0038-0717(93)90140-7

Balzer-Graf, U. R., \& Balzer, F. M. (1989). Round filter chromatography according to Pfeiffer's holistic research method. Labor für Bodenuntersuchungen und Spurenmetall-Analytic Dr. Balzer, Amönau.

Bastos, A. L., Costa, J. P. V., Silva, I. F., Raposo, R. W. C., \& Souto, J. S. (2008). Influence of phosphorus doses in diffusive flow in the soils of Alagoas. Revista Brasileira de Engenharia Agrícola Ambiental, 12(2), 136-142. https://doi.org/10.1590/S1415-43662008000200005

Bezerra, L. P. (2018). Implantação de Sistemas Agroflorestais na Agricultura Familiar: um caminho para a transição agroecológica. Dissertação de Mestrado. São Carlos (SP): Universidade Federal de São Carlos, 105p. https://repositorio.ufscar.br/handle/ufscar/9707

Bhering, S. B. (2008). Mapa de solos do estado do Paraná: legenda atualizada. Ed. Rio de Janeiro:

Imprensa

Oficial. https://www.embrapa.br/busca-de-publicacoes/-/publicacao/578217/mapa-de-solos-do-estado -do-parana-legenda-atualizada

Bopaiah, B. M., \& Shetti, H. S. (1991). Soil microflora and biological activities in the rhizospheres and root regions of coconutbased multistoreyed cropping and coconut monocropping systems. Soil Biology Biochemistry, 23(1), 297-302. https://doi.org/10.1016/0038-0717(91)90167-I

Bradford, J. M., \& Peterson, G. A. (2000). Conservation tillage. In: SUMNER, ME., ed. Handbook of soil science. Boca Raton, CRC Press. p.247-266.

Brasil. (1971). Ministério da agricultura. Levantamento de reconhecimento de solos do nordeste do Paraná. Boletim técnico, 16, Brasília, DF.

Brookes, D. C. (1995). The use of microbial parameters in monitoring soil pollution by heavy metals. Biology and Fertility of Soils, 19, 269-279. https://doi.org/10.1007/BF00336094

Carneiro, M. A. C., Assis, P. C. R., Melo, L. B. D. C., Pereira, H. S., Paulino, H. B., \& Silveira Neto, A. N. (2008). Atributos bioquímicos em dois solos de cerrado sob diferentes sistemas de manejo e uso. Pesquisa Agropecuária Tropical, 38(4), 276-283. https://www.revistas.ufg.br/pat/article/view/3333

Cherubin, M. R., Eitelwein, M. T., Fabbris, C., Weirich, S. W., Silva, R. F., Silva, V. R., \& 
Basso, C. J. (2015). Qualidade física, química e biológica de um Latossolo com diferentes manejos e fertilizantes. Revista Brasileira Ciência do Solo, 39(2), 615-625. https://doi.org/10.1590/01000683rbcs20140462

Da Silva, C. F., Pereira, M. G., Miguel, D. L., Feitora, J. C. F., Loss, A., Menezes, C. E. G., \& da Silva, E. M. R. (2012). Carbono orgânico total, biomassa microbiana e atividade enzimática do solo de áreas agrícolas, florestais e pastagem no médio Vale do Paraíba do Sul (RJ). Revista Brasileira Ciência do Solo, 36(6), 1680-1689. https://doi.org/10.1590/S0100-06832012000600002

De-Polli, H., \& Guerra, J. G. M. (1997). Determinação do carbono da biomassa microbiana do solo: método da fumigação-extração. Embrapa Agrobiologia: Seropédica. (Documento 37). 10p. https://ainfo.cnptia.embrapa.br/digital/bitstream/CNPAB-2010/27227/1/doc037.pdf

Dick, R. P., Breackwell, D. P., \& Turco, R. F. (1996). Soil enzyme activities and biodiversity measurements as integrative microbiological indicators. In Doran, J. W., \& Jones, A. J. (Eds.), Methods for assessing soil quality (pp. 247-271). Madison: Special Publication, 49. https://doi.org/10.2136/sssaspecpub49.c15

Empresa Brasileira de Pesquisa - Embrapa. (1997). Manual de métodos de análise de solo. 2.ed, Centro Nacional de Pesquisa de Solos-CNPS: Rio de Janeiro. 212p. https://www.agencia.cnptia.embrapa.br/Repositorio/Manual+de+Metodos_000fzvhotqk02wx 5ok0q43a0ram31wtr.pdf

Empresa Brasileira de Pesquisa - Embrapa. (2009). Manual de análises químicas de solos, plantas e fertilizantes. 2.ed, Embrapa Informação Tecnológica: Brasília. 627 p. http://livimagens.sct.embrapa.br/amostras/00083136.pdf

Ferreira, E. P. B., Stone, L. F., \& Martin-Didonet, C. C. G. (2017). População e atividade microbiana do solo em sistema agroecológico de produção. Revista Ciência Agronômica, 48(1), 22-31. https://doi.org/10.5935/1806-6690.20170003

Freitas, L., Oliveira, I. A., Silva, L. S., Frare, J. C. V., Filla, V. A., \& Gomes, R. P. (2017). Indicadores da qualidade química e física do solo sob diferentes sistemas de manejo. Revista Unimar Ciências, 26(1), 1-12. http://ojs.unimar.br/index.php/ciencias/article/view/511

Jenkinson, D. S., \& Powlson, D. S. (1976). The effects of biocidal treatments on metabolism in soil-I. Fumigation with chloroform. Soil Biology Biochemistry, 8(3), 167-177. https://doi.org/10.1016/0038-0717(76)90001-8

Júnior, D. D. V., Valadão, F. C. A., \& Silva, G. J. (2017). Organic matter and physical attributes of an oxisol under different management. Revista Ciência Agronômica, 26(3), 237-250. https://ojs.unesp.br/index.php/rculturaagronomica/article/view/2367

Kedi, B., Sei, J., Quiquampoix, H., \& Staunton, A. (2013). Persistence of catalytic activity of fungal phosphatases incubated in tropical soils. Soil Biology Biochemistry, 56, 69-74. https://doi.org/10.1016/j.soilbio.2012.02.005

Kokornaczyk, M. O., Primavera, F., Luneia, R., Baumgartner, S., \& Betti, L. (2016). Analysis of soils by means of Pfeiffer's circular chromatography test and comparison to chemical 
analysis results. Biological Agriculture and Horticulture, 33(3), 143-157. https://doi.org/10.1080/01448765.2016.1214889

Köppen, W. (1931). Climatologia. México, Fundo de Cultura Econômica.

Kuzyakov, Y. (2010). Priming effects: Interactions between living and dead organic matter. Soil Biology Biochemistry, 42(9), 1363-1371. https://doi.org/10.1016/j.soilbio.2010.04.003

Lima, J. S. S., Silva, S. A., Souza, G. S., \& Altoé, M. S. (2017). Multivariate analysis of physical attributes in ultisol from different environments. Revista Engenharia na Agricultura, 25(5), 396-406. https://doi.org/10.13083/reveng.v25i5.790

Lisboa, B. B., Vargas, L. K., Silveira, A. O., Martins, A. F., \& Selbach, P. A. (2012). Indicadores microbianos de qualidade do solo em diferentes sistemas de manejo. Revista Brasileira Ciência do Solo, 36(1), 45-55. https://doi.org/10.1590/S0100-06832012000100004

Loureiro, D.C., De-Polli, H., Aquino, A. M., Sá, M. M. F., \& Guerra, J. G. M. (2016). Influence of soil use on carbon conservation in organic production systems. Revista Brasileira Agroecologia, $\quad 1(1), \quad 1-10$. http://revistas.aba-agroecologia.org.br/index.php/rbagroecologia/article/view/15790/0

Malavolta, E. (1980). Elementos de nutrição mineral de plantas. São Paulo: Ceres, p. 251.

Martínez, V. A., Cruz, L., Ramírez, D. S., \& Alegría, V. A. (2007). Enzyme activities as affected by soil propertiesand land use in a tropical watershed. Applied Soil Ecology, 35(1), 35-45. https://doi.org/10.1590/S0100-06832010000600012

Martins, C. M., Galindo, I. C. L., Souza, E. R., \& Poroca, H. A. (2010). Atributos químicos e microbianos do solo de área sem processo de desertificação no semiárido de Pernambuco. $\begin{array}{lllll}\text { Revista Brasileira Ciência do } & \text { Solo, 34(6), } & \text { 1883-1890. }\end{array}$ http://dx.doi.org/10.1590/S0100-06832010000600012

Maseda, M. T. (2016). Desarrollo y caracterización del método de dinamolisis capilar para el análisis de suelos contaminados: estudio de los suelos de Linares. Tesis Doctoral. Madrid: Universidad Politécnica de Madrid. Spanish. https://doi.org/10.20868/UPM.thesis.39731

Matias, M. C. B. S., Salviano, A. A. C., Leite, L. F. C., \& Araújo, A. S. F. (2009). Biomassa microbiana e estoques de $\mathrm{C}$ e $\mathrm{N}$ do solo em diferentes sistemas de manejo, no Cerrado do estado do Piauí. Acta Scientiarum Agronomy 31(3), 517-521. https://doi.org/10.4025/actasciagron.v31i3.687

Matsuoka, M., Mendes, I. C., \& Loureiro, M. F. (2003). Biomassa microbiana e atividade enzimática em solos sob vegetação nativa e sistemas agrícolas anuais e perenes na região de Primavera do Leste (MT). Revista Brasileira Ciência do Solo, 27(3), 425-433. https://doi.org/10.1590/S0100-06832003000300004

Melloni, R., Pereira, E. G. M., \& Alvarenga, M. I. N. (2008). Indicadores da qualidade do solo. Informativo Agropecuário, 29(244), 17-29.

Mendes, I. C., Sousa, D. M. G., \& Reis Junior, F. B. (2015). Bioindicadores de qualidade de solo: dos laboratórios de pesquisa para o campo. Caderno de Ciências \& Tecnologia, 32(1/2), 
191-209. http://dx.doi.org/10.35977/0104-1096.cct2015.v32.23311

Moreira, A., Carvalho, J. G., \& Evangelista, A. R. (1999). Influência da relação cálcio: magnésio do corretivo na nodulação, produção e composição mineral da alfafa. Pesquisa agropecuária brasileira, 34(2), 249-255. https://doi.org/10.1590/S0100-204X1999000200014

Moreira, F. M. S., \& Siqueira, J. O. (2006). Microbiologia e Bioquímica do Solo. (2nd ed.). Lavras: Universidade Federal de Lavras. p. 729.

Nannipieri, P., Giagnoni, L., Landi, L., \& Renella, G. (2011). Role of phosphatase enzymes in soil. In: Bünemann, E.K., Oberson, A., Frossard, E. (Eds.), Phosphorus in Action, Series: Soil Biology, 26, 215-243. https://doi.org/10.1007/978-3-642-15271-9_9

Nogueira, M. A., \& Melo, W. J. (2003). Enxofre disponível para a soja e atividade de arilsulfatase em solo tratado com gesso agrícola. Revista Brasileira Ciência do Solo, 27(4), 655-663. https://doi.org/10.1590/S0100-06832003000400010

Odum, E. P. (1985). Trends expected in stressed ecosystems. BioScience, 35(7), 419-422. https://doi.org/10.2307/1310021

Perumal, K., Ananthi, S., \& Arunkumar, J. (2016). Innovative and simplest Alternative Analytical Technology (AAT) for testing soil nutrients. Soil Science Reserch, 1(1), 22-31.

Pfeiffer, E. E. (1984). Chromatography applied to quality testing. Wyoming: Bio-Dynamic Farming and Gardening Association. p. 44.

Polson, D. S., \& Brookes, P. C. (1987). Measurement of soil microbial biomass provides an early indication of changes in total soil organic matter due to straw incorporation. Soil Biology Biochemistry, 19(2), 159-164. https://doi.org/10.1016/0038-0717(87)90076-9

Portugal, A. F., Costa, O. D. V, Costa, L. M. E., \& Santos, B. C. M. (2008). Soil chemical and physical attributes of aninceptisol under different land uses, in the zonada mata of minas gerais state, brazil. Revista Brasileira Ciências do Solo, 32(1), 249-258. https://doi.org/10.1590/S0100-06832008000100024

Primavesi, A. (1982). Manejo ecológico do solo: agricultura em regiões tropicais. São Paulo: Nobel, p. 549.

R Core Team. (2016). R: A language and environment for statistical computing. R Foundation for Statistical Computing, Vienna, Austria. https://www.R-project.org/

Rangel, O. J. P., \& Silva, C. A. (2007). Estoques de carbono e nitrogênio e frações orgânicas de Latossolo submetido a diferentes sistemas de uso e manejo. Revista Brasileira Ciência do Solo, 31(6), 1609-1623. https://doi.org/10.1590/S0100-06832007000600037

Restrepo, J. R., \& Pinheiro, S. (2011). Cromatografía: imágenes de vida y destruccíon del suelo. Cali: Feriva. p. 252.

Silva, A. S. D., Colozzi Filho, A., Nakatani, A. S., Alves, S. J., Andrade, D. D. S., \& Guimarães, M. D. F. (2015). Microbial characteristics of soils under an integrated crop-livestock system. Revista Brasileira Ciência do Solo, 39(1), 40-48. 
https://doi.org/10.1590/01000683rbcs20150185

Soiltech Solutions: Chromabeoordeling. 2005-2018. Biezenmortel-Netherlands. https://www.bio-ron.com/images/stories/files/chroma-analyze.pdf.

Souza, E. D., \& Costa, Sevga, Anghinoni, I., Lima, C.V.S., Carvalho, P.C.F., \& Martins, A.P. (2010). Biomassa microbiana do solo em sistema de integração-lavoura em plantio direto, submetido a intensidade de pastejo. Revista Brasileira Ciência do Solo, 34(1), 79-88. https://doi.org/10.1590/S0100-06832010000100008

Stott, D. E., Andrews, S. S., Liebig, M. A., Wienhold, B. J., \& Karlen, D. L. (2010). Evaluation of $\beta$-glucosidase activity as a soil quality indicator for the soil management assessment framework. Soil Science Society of America Journal, 74(1), 107-119. https://doi.org/10.2136/sssaj2009.0029

Tabatabai, M. A. (1994.) Soil enzymes. In: Weaver R. W., Angle, J. S., Bottomley, P. S., Bezdicek, D., Smith, S., Tabatabai, A., \& Wollum, A. (Eds.). Methods of soil analysis. Part 2. Microbiological and biochemical properties. Madison: Soil Science Society of America Journal, 5, 775-833.

Tedesco, M. J., Gianello, C., Bissani, C. A., \& Volkweiss, S. J. (1995). Análises de solo, plantas e outros materiais. (2nd ed.). Porto Alegre: Universidade Federal do Rio Grande do Sul. Boletim Técnico, 5. p.174.

Verchot, L. V., \& Borelli, T. (2005). Application of para-nitrophenol (pNP) enzyme assays in degraded tropical soils. Soil Biology Biochemistry, 37(4), 625-633. https://doi.org/10.1016/j.soilbio.2004.09.005

Walkley, A., \& Black, I. A. (1934). An examination of the degtjareff method for determining soil organic matter, and proposed modification of chromic acid titration method. Soil Science, 37, 29-38. https://doi.org/10.1097/00010694-193401000-00003

Wardle, D. A. (1994). Metodologia para quantificação da biomassa microbiana do solo. In Hungria, M., \& Araujo, R. S. (Ed.). Manual de métodos empregados em estudos de microbiologia agrícola. Brasília: Embrapa Serviço de Produção de Informação, Santo Antônio de Goiás: Embrapa Centro Nacional de Pesquisa de Arroz e Feijão, Londrina: Embrapa Soja, 419-436. https://www.embrapa.br/busca-de-publicacoes/-/publicacao/199952/manual-de-metodos-emp regados-em-estudos-de-microbiologia-agricola

\section{Copyright Disclaimer}

Copyright for this article is retained by the author(s), with first publication rights granted to the journal.

This is an open-access article distributed under the terms and conditions of the Creative Commons Attribution license (http://creativecommons.org/licenses/by/4.0/). 